\title{
Studies on Temperature Influence on Oviposition and Development of Immature Stages of the Yam Beetle Dinoderus Porcellus Lesne. Coleoptera: Bostrichidae on Dried Yam Species
}

\author{
M.O. Oni (Corresponding Author) \\ Department of Biology, Adeyemi College of Education, Ondo, Ondo State, Nigeria \\ A.O. Omoniyi \\ Department of Science and Environmental Education, Faculty of Education \\ University of Abuja F.C.T, Nigeria \\ Tel: 234-803-430-0943Ｅ-mail: mercyyinka2007@yahoo.co.uk
}

\author{
Received: June 13, 2011 \\ Accepted: July 7, $2011 \quad$ Online Published: December 21, 2011 \\ doi:10.5539/jas.v4n2p213 \\ URL: http://dx.doi.org/10.5539/jas.v4n2p213
}

\begin{abstract}
Teneral adults of Dinoderus porcellus were raised in the laboratory and exposed to various temperature regimes $10^{\circ}, 15^{\circ}, 20^{\circ}, 30^{\circ}, 35^{\circ}$ and $40^{\circ} \mathrm{C}$ respectively. Four dried yam species Dioscorea rotundata, Dioscorea alata, Dioscorea dumetorum and Dioscorea cayenensis were used, to determine the effect of temperature on oviposition and developmental stages of the insect. At $10^{\circ} \mathrm{C}$, there was no oviposition, at $15^{\circ} \mathrm{C}$ fewer eggs were laid. Oviposition increases with little variation as temperature increases from $20^{\circ} \mathrm{C} 30^{\circ} \mathrm{C}$. There is reduction in the number of eggs laid at $35^{\circ} \mathrm{C}$, while zero oviposition was recorded at $40^{\circ} \mathrm{C}$. Egg incubation ranges between 6 to 8 days and there were significance difference $(\mathrm{P}<0.05)$ in the developmental period of larva and no significance difference $(\mathrm{P}<0.05)$ at the pupal stage. However, developmental period was prolonged on Dioscorea cayenensis as temperature increases.
\end{abstract}

Keywords: Oviposition, Immature stages, Dried yam species, Temperature

\section{Introduction}

Preliminary investigation of insects collected in descending order of frequency in a survey of insect infestation on dried yams, Dinoderus porcellus. Lesne, Araecerus fasciculatus DeGeer, Sitophilus zeamais. Motsch and Tribolium castaneum. Herbst, Dinoderus. porcellus and Rhizoperta dominica Fab was observed as the most abundant in dried yams. (Adesuyi, 1967; Osuji, 1980). Dinoderus porcellus is mainly associated with dried yam and yam products and closely resembles the lesser grain borer Rhizoperta. dominica in general appearance, biology and habits (Osuji, 1985) Araecerus fasciculatus and. Sitophilus zeamais are reported to be generally associated with many stored products, most especially cereals and grains (Ofuya, T. I. \& Lale N.E.S (2002); Zaidi \& Singh, 2005; Stoll, 2000; Pedigo and Rice, 2006; Osunde, 2008; Osagie, 1992), Dinoderus porcellus is a major pest in dry yams (Adesuyi, 1997; Osuji, 1980; Oni, 1995).

Studies on temperature influence on biology of Dinoderus porcellus has not been given due attention as other stored product insects. The mean developmental period of Dinoderus porcellus on dried yam was reported to be 35.9 days at ambient temperature (Nwana, 1993). A temperature of $28^{0}-30^{\circ} \mathrm{C}$ favours the development of Rhizoperta. dominica (Osuji 1980; 1985). At 20 $0^{\circ} \mathrm{C}$, the Khapra beetles Trogoderma granarium were inactive and laid no eggs, while at $27^{\circ} \mathrm{C}$ to $35^{\circ} \mathrm{C}$, eggs laid showed little variations as temperature increases (Odeyemi \& Hassan, 1992). This study investigated temperature influence on oviposition and development of immature stages of the yam beetle, Dinoderus porcellus on dried yam species.

\section{Materials and Methods}

This study was conducted in Post-graduate research laboratory of the Department of Biology, Federal University of Technology, Akure, Ondo State, Nigeria. 


\subsection{Insect Culture}

Adult Dinoderus porcellus were obtained from selected local dried yam markets in Akure, Nigeria. Insecticide-free and uninfested samples of dried yam from the same market was heat sterilized in an oven at $105^{\circ} \mathrm{C}$ for $2 \mathrm{hr}$ to kill hidden insects, eggs and other contaminants. Insect colonies were raised by infesting the disinfected dried yam chips with 20 adults of Dinoderus porcellus of both sexes in a kilner jar. The kilner jars were kept in the laboratory at fluctuating temperature of $20-30^{\circ} \mathrm{C}$ and a relative humidity of $75 \pm 5 \%$, subsequent teneral adults used for the study were raised from this culture for subsequent experiment (Adedire \& Oni, 1998).

\subsection{Preparation of dried yam species}

Samples of four dried yam species used in this study were prepared from fresh tubers of Dioscorea rotundata, Dioscorea alata, Dioscorea dumetorum and Dioscorea cayenensis (Table 1). The fresh yam tubers were processed and each dried yam species were pulverized into fine yam flour using mortar and pestle and sieved with sieved No. 10 to obtain fine powder while large fibrous particles were removed and discarded (Coursey, 1996: Idoko \& Adebayo, 2011) and used for subsequent assays.

\subsection{Temperature and Oviposition}

Five grams $(5 \mathrm{~g})$ of each dried yam specie were weighed into petri-dishes. Five pairs of adult Dinoderus porcellus (1 -2 days old) were introduced into each Petri-dish, covered with muslin cloth held in place by a rubber band. This was to allow adequate aeration and prevent escape of insects. Sex of adults was determined using size and antennal characters according to Halstead (1963).

Oviposition was monitored over constant temperatures of $10,15,20,25,30,35$ and $40^{\circ} \mathrm{C}$ in a cooled Gallenhamp incubator model 2C / 1525 and R216GA and the number of eggs laid and period of incubation was recorded.

\subsection{Temperature and Developmental Stages}

Developmental stages of Dinoderus porcellus were also determined. One day old larva collected from sets of incubated eggs was placed in a petri-dish containing $5.0 \mathrm{~g}$ of dried yam flour and covered with muslin cloth held in place by a rubber band. All the four variants of yam species (flour) were used at each temperature ranges for incubation of eggs in Gallenhamp cooled incubator. Treatment was replicated four times at each temperature tested. Period of development of larva to pupa were observed and recorded until adult emergence on each dried yam species tested.

\subsection{Statistical Analysis}

Data obtained were subjected to analysis of variance (ANOVA) and mean separation was carried out using New Duncan's Multiple Range Test (DUNCAN).

\section{Results}

\subsection{Temperature effect on Oviposition}

There was no oviposition at $10^{\circ} \mathrm{C}$, while at $15^{\circ} \mathrm{C}$ few eggs were laid (Table 2). As the temperature increased from $20^{\circ} \mathrm{C}$ to $30^{\circ} \mathrm{C}$, the number of eggs laid increased and showed little variation. There was a slight decrease in the number of eggs laid at $35^{\circ} \mathrm{C}$ on all the dried yam species tested while at $40^{\circ} \mathrm{C}$ there was no oviposition. All insects died second day after pairing them at $40^{\circ} \mathrm{C}$. Significantly, Dioscerea alata and Dioscorea dumetorum, than recorded on Dioscorea cayenensis at all temperature regimes tested (Table 2).

Statistically, the mean number of eggs laid in Discorea rotundata showed no significant difference at $(\mathrm{P}<0.05)$ probability level between the temperature ranges of $20^{\circ} \mathrm{C}, 25^{\circ} \mathrm{C}$ and $30^{\circ} \mathrm{C}$ while a significant difference occurred between mean numbers of eggs oviposited at $15^{\circ} \mathrm{C}$ when compared to those exposed to higher temperatures. On Dioscorea alata and Dioscorea dumetorum, there was a significant difference $(\mathrm{P}<0.05)$ in the number of eggs laid at $15^{\circ} \mathrm{C}$ and $20^{\circ} \mathrm{C}$ while no significant difference was established between $25^{\circ} \mathrm{C}, 30^{\circ} \mathrm{C}$ and $35^{\circ} \mathrm{C}$. However, on Dioscorea cayenensis, no significant difference was recorded between the temperature regimes tested $(\mathrm{P}<0.05)$.

\subsection{Temperature Effect on Development of Immature Stages of Dinoderus porcellus}

At $10^{\circ} \mathrm{C}$, no eggs were laid, so no further development was observed. Egg incubation period ranges between 4.5 to 8.75 days across the temperatures $20^{\circ} \mathrm{C}$ to $35^{\circ} \mathrm{C}$. A prolonged incubation period of 8.75 days was recorded on Dioscorea cayenensis at $15^{\circ} \mathrm{C}$ when compared with other temperature $20-35^{\circ} \mathrm{C}$ (Table 3 ). 
Development of larva terminated at the second instar stage with a delayed developmental period of $40-42$ days on all the dried yam species and at this stage mortality of the larva occurred. Analysis of variance test showed that, there were significant difference in the developmental period of larva at $5 \%$ probability level between the temperature ranges $20^{\circ} \mathrm{C}$ to $35^{\circ} \mathrm{C}$ (Table $3-5$ ) showed that there were no significant difference $(\mathrm{P}<0.05)$ on the pupal's period of development between the temperature regimes on Dioscorea alata and Dioscorea dumetorum. The pupal stage lasted 5.25 to 6.50 days. Further test using Duncan's multiple range test confirmed that there was no marked difference on the total development period on the four dried yam species.

\section{Discussion}

This study shows the temperature variation influence on oviposition and development of immature stages of Dinoderus porcellus. At $10^{\circ} \mathrm{C}$, the beetles were chilled and inactive, hence there was no oviposition, while at $15^{\circ} \mathrm{C}$, few eggs were laid. The increase in the number of eggs laid as temperature increased from $20^{\circ} \mathrm{C}$ to $35^{\circ} \mathrm{C}$ may be attributed to increased temperature and similar to observation on Corcyra cephalonica that oviposition increases as temperature increases (Rao, 1954). However at $40^{\circ} \mathrm{C}$, there was no oviposition and all the insect pairs died second day after pairing. This temperature regime was probably too high for the survival and further development of the beetles. Similar response was reported at $20^{\circ} \mathrm{C}$, as Trogoderma granarium become inactive and eggs were not laid, while little variation was reported in eggs laid at $27^{\circ} \mathrm{C}$ and $35^{\circ} \mathrm{C}$ (Odeyemi \& Hassan, 1992).

Temperature parameter had a slight effect on different stages of Dinoderus porcellus. A longer period of incubation was recorded at $15^{\circ} \mathrm{C}$ than obtained at $20^{\circ} \mathrm{C}$ to $35^{\circ} \mathrm{C}$. At this temperature $\left(15^{\circ} \mathrm{C}\right)$ all the larva died after a delayed developmental period of $40-42$ days. This may be attributed to a low temperature tolerance. This results confirmed reports of previous work by Bowley et al, 1987 on Corcyra cephalonica on wheat that at $15^{\circ} \mathrm{C}$ and $70 \%$ R.H all the larva died young. In contrast to his observation Voelkel, (1974) observed development at $15^{\circ} \mathrm{c}$. No significant difference was recorded from larva to adult stage $(\mathrm{P}<0.05)$ across the temperature $20^{\circ} \mathrm{c}$ to $35^{\circ} \mathrm{C}$.

\section{Conclusion and Recommendation.}

It was observed from the laboratory results of rearing Dinoderus porcellus at controlled temperatures and relative humidity $75 \pm 5 \% \mathrm{~b}$ that, the favourable temperature range for the development of Dinoderus porcellus was from $20^{\circ} \mathrm{C}$ to $35^{\circ} \mathrm{C}$. At temperatures below this range, development was much slower as recorded at $15^{\circ} \mathrm{C}$. The significant delay in the developmental period of the dried yam beetle could be attributed to the presence of some anti-nutritional factors. Oni, 1995; Adedire \& Oni, 1998 affirmed that, this may be attributed to low protein content of Dioscorea cayenensis and the presence of some anti-nutritional factors. In a similar vein, Kochlar 1986 was of the opinion that, low preference for Dioscorea cayenensis may be due to the presence of alkaloids present in some yam species.

From the view point of this study, the storage of dried yams at temperature below $20^{\circ} \mathrm{C}$ and above $35^{\circ} \mathrm{C}$ is suggested, since the insects are unable to develop outside this temperature range $\left(20^{\circ} \mathrm{C}\right.$ to $\left.35^{\circ} \mathrm{C}\right)$ and a good recommendation for management of insect pests, since infestation is not likely to develop at these temperature ranges

Consequently, the economic significance Dinoderus porcellus on dried yam chips and on other stored products requires an urgent attention in country like Nigeria being $90-95 \%$ of yam's world producer (Osunde, 2008), and a major consumer of dried yam chips. In view of this, further studies require the identification of the chemical substance responsible for the significant delay in the development of the beetle on Dioscorea cayenensis is important. This chemical substance could serve as preservative to other yam species from the development of the beetle Dinoderus porcellus and other storage coleopterans on dried yam chips.

\section{References}

Adedire, C.O. \& Oni, M.O. (1998). Effect of host species on oviposition and development of the yam beetle Dinoderus porcellus Lesne (Coleoptera: Bostrichidae). ESN Occational Publication, 31:243-248.

Adesuyi, S.A. (1967). A survey of insect pests on dried yam and an investigation of the biology of the important species Rep. Nigeria in Stored Product Research Inst. Tech pp95-99.

Adesuyi, S.A. (1971). A survey of moisture content and insect infestation pattern on dried yams for twenty-one months in the market at Ibadan (Western State). Report of Nigeria Stored Products Research Institute, 10:65-71.

Coursey, D.G. (1966). Food technology and yam in West Africa. Tropical Science, 7:152-159. 
Halstead, G.H. (1963). External Sex differences in stored products Coleoptera. Bulletin of Entomological Research, 54:119-134. http://dx.doi.org/10.1017/S0007485300048665

Idoko, J.E. \& Adebayo, R.A. (2011). Effect of Dennettia tripetala powder and Reduced Rates of Pirimiphes-Methyl Singly and combined in management of Callosobruchus maculates (F.) (Coleoptera: Bruchidae) International Journal of Biology, 3(2): 174-176. http://dx.doi.org/10.5539/ijb.v3n2p174

Kocklar, S.L. (1986). Tropical Crops. A Textbook of Economic Botany. Macmillian, London. pp.467.

Nwanna, I.E. (1993). A survey of storage Coleoptera which attack dried cocoyam chips in Nigeria. Journal of stored Products Research, 29:95-98. http://dx.doi.org/10.1016/0022-474X(93)90028-3

Odeyemi, O.O. \& Hassan, A.T. (1992). Influence of Temperature, Humidity and photoperiod on oviposition and larval development in Trogoderma granarium (Everts) Coleoptera: Dermestidae. Applied Entomology, Zool., 28:275-281.

Ofuya, T.I \& Lale, N.E.S. (2002). Pests of Stored cereals and Pulse in Nigeria. Biology, Ecology and control., Dave Collins Publication, Nigeria. pp.173.

Oni, M.O. (1995). Studies on the developmental biology of the dried yam bettle Dinoderus porcellus lesne (Coleoptera: Bostrichidae). Unpublished M. Tech Thesis, Federal University of Technology, Akure. Nigeria.

Osagie, A.U. (1992). The yam tuber in storage. Post Harvest Research Unit, Dept of Biochemistry, University of Benin Nigeria.

Osuji, F.N.C. (1980). Observation on the beetles on dried yams and yam flour from three Nigerian markets. Tropical Stored Products Research Institute, 39:35-38.

Osuji, F.N.C. (1985). Outlines of stored products entomology for the tropics. Fourth Dimension Publishers, Enugu, Nigeria. p.103.

Osunde, Z.D. (2008). Minimizing post harvest losses in yam (Dioscorea, spp): treatment techniques. In: Robertson, G.L., Lupien, J.R (Eds) Using Food Science and Technology to improve Nutrition and Promote National Development International Union of Food Science and Technology- Chapter 12, pp.1-12.

Pedigo, L.P \& Rice, M.E. (2006). Entomology and Pest Management. Pearson Prentice Hall, New Jersey USA. $749 \mathrm{pp}$.

Rao. D.S. (1954). Notes on rice moth Corcyra cephalonica (Staint) (Lepidoptera: Galleridae) on millet and sorghum at $28^{\circ} \mathrm{C}$ and different relative humidities. Z- angrew. Ent., 89.488-489.

Stoll, G. (2000). Natural Crop Protection in the Tropics, $2^{\text {nd }}$ Edition, Margrav Verlag. Weikersheim Germany. 376pp.

Voelkel, H. Zur. (1974). Billogy Und Bekampfung des Khaprakafers, Trogoderma granarium Everts. Arbbid. Reichsant Landu. Forstuiv. 13. 129-171. In J. Stored. Prod. Res., 13:183-202.

Table 1. Yam Species used in this study

\begin{tabular}{|l|l|}
\hline Yam species & Common name \\
\hline Dioscorea rotundata & White yam \\
\hline Dioscorea alata & Water yam \\
\hline Dioscorea dumetorum & Wild yam \\
\hline Dioscorea cayenensis & Yellow yam \\
\hline
\end{tabular}


Table 2. Mean egg (mean $\pm \mathrm{SD}$ ) oviposited by female Dinoderus porcellus on dried yam species at various temperature

\begin{tabular}{|c|c|c|c|c|c|c|c|}
\hline Dried yam species & $10^{0} \mathrm{c}$ & $15^{\circ} \mathrm{c}$ & $20^{\circ} \mathrm{c}$ & $25^{\circ} \mathrm{c}$ & $30^{\circ} \mathrm{c}$ & $35^{\circ} \mathrm{c}$ & $40^{\circ} \mathrm{c}$ \\
\hline Dioscorea. rotundata & - & $21.5 \pm 1.19 \mathrm{~b}$ & $25 \pm 1.03 \mathrm{ab}$ & $33.5 \pm 1.32 \mathrm{a}$ & $35.0 \pm 0.41 \mathrm{a}$ & $34.0 \pm 2.16 \mathrm{a}$ & - \\
\hline Dioscorea alata & - & $20.75 \pm 1.38 \mathrm{c}$ & $26.75 \pm 0.85 b$ & $33.5+1.89 \mathrm{a}$ & $32.75 \pm 1.89 a$ & $32.75 \pm 1.89 \mathrm{a}$ & - \\
\hline Dioscorea dumetorum & - & $19.75 \pm 0.63 \mathrm{c}$ & $24.5 \pm 0.65 b$ & $31.25 \pm 1.11 \mathrm{a}$ & $32.25 \pm 2.01 \mathrm{a}$ & $29.0 \pm 0.91 \mathrm{~b}$ & - \\
\hline Diocorea cayenensis & - & $6.5 \pm 1.19 \mathrm{a}$ & $9.25 \pm 0.85 a$ & $8.5 \pm 1.11 \mathrm{a}$ & $9.25 \pm 1.11 \mathrm{a}$ & $7.25 \pm 1.11 \mathrm{a}$ & - \\
\hline
\end{tabular}

* Each value is a mean of 4 replicates \pm standard error of the mean. Means followed by same letter(s) are not significantly different $(\mathrm{P}<0.05)$ by New Duncan's multiple range test.

Table 3. Temperature variation on immature stages of Dinoderus porcellus on Diocorea rotundata

Temperature

Period of development (days)

\begin{tabular}{|l|l|l|l|l|}
\hline \multicolumn{1}{|c|}{${ }^{\mathbf{0}} \mathbf{C}$} & \multicolumn{1}{c|}{ Egg incubation } & \multicolumn{1}{c|}{ Larva } & \multicolumn{1}{c|}{ Pupal } & \multicolumn{1}{c|}{ Total } \\
\hline 15 & $7.25 \pm 0.25 \mathrm{a}$ & - & - & - \\
\hline 20 & $4.50 \pm 0.29 \mathrm{a}$ & $25.75 \pm 0.48 \mathrm{a}$ & $6.25 \pm 0.25 \mathrm{a}$ & $36.75 \pm 0.25 \mathrm{a}$ \\
\hline 25 & $5.75 \pm 0.25 \mathrm{~b}$ & $23.25 \pm 1.11 \mathrm{a}$ & $5.5 \pm 0.29 \mathrm{a}$ & $34.25 \pm 1.11 \mathrm{a}$ \\
\hline 30 & $5.25 \pm 0.48 \mathrm{bc}$ & $24.25 \pm 0.48 \mathrm{a}$ & $5.5 \pm 0.29 \mathrm{a}$ & $35.0 \pm 0.71 \mathrm{a}$ \\
\hline 35 & $5.25 \pm 0.25 \mathrm{bc}$ & $24.75 \pm 0.48 \mathrm{a}$ & $5.5 \pm 0.25 \mathrm{a}$ & $35.25 \pm 0.75 \mathrm{a}$ \\
\hline
\end{tabular}

- no development

Each value is a mean of 4 replicates \pm standard error of the mean. Means followed by the same letter(s) are not significantly different $(\mathrm{P}<0.05)$ by Duncan's multiple range test.

Table 4. Temperature variation on the development immature stages of Dinoderus. porcellus on Dioscorea alata Temperature Period of development (days)

\begin{tabular}{|l|l|l|l|l|}
\hline \multicolumn{1}{|c|}{${ }^{\mathbf{0}} \mathbf{C}$} & \multicolumn{1}{|c|}{ Egg incubation } & \multicolumn{1}{c|}{ Larva } & \multicolumn{1}{c|}{ Pupal } & \multicolumn{1}{c|}{ Total } \\
\hline 15 & $6.50 \pm 0.65 \mathrm{a}$ & \multicolumn{1}{c|}{-} & - & - \\
\hline 20 & $5.00 \pm 0.22 \mathrm{~b}$ & $25.0 \pm 0.41 \mathrm{a}$ & $4.25 \pm 0.48 \mathrm{a}$ & $35.75 \pm 0.25 \mathrm{a}$ \\
\hline 25 & $5.25 \pm 0.29 \mathrm{a}$ & $24.25 \pm 0.63 \mathrm{a}$ & $5.75 \pm 0.25 \mathrm{a}$ & $35.0 \pm 0.41 \mathrm{a}$ \\
\hline 30 & $5.0 \pm 0.41 \mathrm{~b}$ & $24.75 \pm 0.48 \mathrm{a}$ & $5.5 \pm 0.5 \mathrm{a}$ & $35.0 \pm 0.58 \mathrm{a}$ \\
\hline 35 & $5.75 \pm 0.43 \mathrm{ab}$ & $24.5 \pm 2.04 \mathrm{a}$ & $5.25 \pm 0.25 \mathrm{a}$ & $35.25 \pm 0.48 \mathrm{a}$ \\
\hline
\end{tabular}

- no development

Each value is a mean of 4 replicates \pm standard error of the mean

Means followed by the same letter(s) are not significantly different $(\mathrm{P}<0.05)$ by Duncan's multiple range test. 
Table 5. Temperature variation on the development of immature stages Dinoderus porcellus on Dioscorea. dumetorum

Temperature

\begin{tabular}{|l|l|l|l|l|}
\hline${ }^{\mathbf{0}} \mathbf{C}$ & \multicolumn{1}{|c|}{ Egg incubation } & \multicolumn{1}{c|}{ Larva } & \multicolumn{1}{c|}{ Pupal } & \multicolumn{1}{c|}{ Total } \\
\hline 15 & $6.50 \pm 0.50 \mathrm{a}$ & - & - & - \\
\hline 20 & $5.0 \pm 0.22 \mathrm{a}$ & $25.0 \pm 0.41 \mathrm{a}$ & $6.0 \pm 0.41 \mathrm{a}$ & $36.0 \pm 0.41 \mathrm{a}$ \\
\hline 25 & $5.0 \pm 0.22 \mathrm{a}$ & $24.25 \pm 0.48 \mathrm{a}$ & $5.75 \pm 0.25 \mathrm{a}$ & $35.0 \pm 0.41 \mathrm{a}$ \\
\hline 30 & $4.75 \pm 0.42 \mathrm{~b}$ & $25.5 \pm 0.29 \mathrm{a}$ & $5.75 \pm 0.25 \mathrm{a}$ & $36.0 \pm 0.25 \mathrm{a}$ \\
\hline 35 & $5.0 \pm 0.22 \mathrm{a}$ & $25.5 \pm 0.29 \mathrm{a}$ & $5.75 \pm 0.25 \mathrm{a}$ & $36.0 \pm 0.25 \mathrm{a}$ \\
\hline
\end{tabular}

- no development

Each value is a mean of 4 replicate \pm standard error of the mean. Means followed by the same letter(s) are not significant different at $(\mathrm{P}<0.05)$ by Duncan's multiple range test.

Table 6. Temperature variation on the development of immature stages of Dinoderus porcellus on Dioscorea cayenensis.

Temperature

Period of development

\begin{tabular}{|l|l|l|l|l|}
\hline \multicolumn{1}{|c|}{${ }^{\mathbf{0}} \mathbf{C}$} & \multicolumn{1}{c|}{ Egg incubation } & \multicolumn{1}{c|}{ Larva } & \multicolumn{1}{c|}{ Pupal } & \multicolumn{1}{c|}{ Total } \\
\hline 15 & $8.75 \pm 0.25 \mathrm{a}$ & \multicolumn{1}{c|}{-} & \multicolumn{1}{c|}{-} \\
\hline 20 & $5.75 \pm 0.42 \mathrm{~b}$ & $27.0 \pm 0.58 \mathrm{a}$ & $5.5 \pm 0.29 \mathrm{a}$ & $38.25 \pm 0.25 \mathrm{a}$ \\
\hline 25 & $6.50 \pm 0.06 \mathrm{a}$ & $26.5 \pm 0.29 \mathrm{a}$ & $5.75 \pm 0.25 \mathrm{a}$ & $38.75 \pm 0.25 \mathrm{a}$ \\
\hline 30 & $6.50 \pm 0.06 \mathrm{~b}$ & $25.5 \pm 0.29 \mathrm{a}$ & $6.5 \pm 0.29 \mathrm{a}$ & $38.5 \pm 0.29 \mathrm{a}$ \\
\hline 35 & $6.0 \pm 0.42 \mathrm{~b}$ & $26.5 \pm 0.48 \mathrm{a}$ & $6.0 \pm 0.41 \mathrm{a}$ & $38.0 \pm 0.65 \mathrm{a}$ \\
\hline
\end{tabular}

- no development

Each value is a mean of 4 replicates \pm standard error of the mean. Means followed by the same letter(s) are not significantly different at $(\mathrm{P}<0.05)$ by Duncan's multiple range test. 